\title{
Analysis of Cigarette Smoke Deposition Within an In Vitro Exposure System for Simulating Exposure in the Human Respiratory Tract *
}

\author{
by \\ Shinkichi Ishikawa, Takuya Suzuki, and Yasufumi Nagata \\ Scientific Product Assessment Center, R\&D Group, Japan Tobacco, Yokohama, Japan
}

\section{SUMMARY}

For the risk assessment of airborne chemicals, a variety of in vitro direct exposure systems have been developed to replicate airborne chemical exposure in vivo. Since cells at the air-liquid interface are exposed to cigarette smoke as an aerosol in direct exposure systems, it is possible to reproduce the situation of cigarette smoke exposure in the human respiratory system using this device. However it is difficult to know whether the exposed cigarette smoke in this system is consistent with the smoke retained in the human respiratory tract. The purpose of this study is to clarify this point using the CULTEX ${ }^{\circledR}$ RFS module which is a recently developed direct exposure system. For this purpose, solanesol and acetaldehyde were respectively chosen as the particulate and gas/vapor phase representatives of smoke constituents, and their deposition and balance per unit area of cell culture surface of the RFS module were measured (dosimetry). We also conducted human retention studies to compare with the dosimetry data. By comparing inhaled smoke and exhaled smoke under three inhalation conditions, we estimated the regional retention and balance of each representative per unit surface area of the respiratory tract (mouth, bronchi, and alveoli separately). The deposition of solanesol and acetaldehyde per unit area of cell culture surface in the RFS module decreased dependent on the dilution flow rate and ranged from $0.26-0.0076 \% / \mathrm{cm}^{2}$ in our experimental conditions. The ratio of deposited acetaldehyde to deposited solanesol ranged from 0.96-1.96 in the RFS module. The retention of solanesol and acetalde- hyde per unit surface area in the mouth and the bronchi ranged from $0.095-0.0083 \% / \mathrm{cm}^{2}$ in this study. The retention per unit surface area of alveoli was far lower than in the other two regions $\left(0.0000063 \% / \mathrm{cm}^{2}\right)$. The ratio of retained acetaldehyde to retained solanesol ranged from 0.54-1.97. From these results, we concluded that the CULTEX $^{\circledR}$ RFS module can simulate in vivo cigarette smoke exposure in terms of the exposed particulate and gas/vapor phase chemical balance. We also found that the exposure in this module could replicate the retention in the mouth and the bronchi. [Beitr. Tabakforsch. Int. 27 (2016) 20-29]

\section{ZUSAMMENFASSUNG}

Zur Risikobewertung von chemischen Schwebstoffen wurde eine Reihe von Systemen zur direkten in vitro Exposition entwickelt, um die Exposition gegenüber solchen Chemikalien in vivo zu replizieren. Da Zellen in Systemen zur direkten Exposition an der Luft-Flüssigkeitsgrenze dem Zigarettenrauch in Form eines Aerosols ausgesetzt sind, lässt sich mit diesem Gerät die Situation der Zigarettenrauchexposition im menschlichen Atmungssystem nachbilden. Es ist jedoch schwierig festzustellen, ob die Zigarettenrauchexposition in diesem System mit der Rauchexposition im menschlichen Atmungsapparat übereinstimmt. Zweck der vorliegenden Studie ist, diesen Punkt unter Verwendung des CULTEX ${ }^{\circledR}$ RFS-Moduls zu klären, einem System der Direktexposition, welches vor kurzem 
entwickelt wurde. Zu diesem Zweck wurden Solanesol bzw. Acetaldehyd als stellvertretende Bestandteile für die Partikel- und Gas/Dampfphase, die Bestandteil des Rauchs sind, ausgewählt, und es wurden ihre Ablagerung und Bilanz pro Flächeneinheit der Zellkulturoberfläche des RFS-Moduls gemessen (Dosimetrie). Außerdem wurden Retentionsstudien am Menschen zum Vergleich mit den dosimetrischen Daten durchgeführt. Durch den Vergleich von eingeatmetem und ausgeatmetem Rauch unter drei Inhalationsbedingungen wurde die regionale Retention und Bilanz jedes Vertreters pro Flächeneinheit der Atemwege (Mund, Bronchien und Alveolen separat) geschätzt. Die Ablagerung von Solanesol und Acetaldehyd pro Flächeneinheit der Zellkulturoberfläche im RFS-Modul verringerte sich in Abhängigkeit von der Verdünnungsflussrate und lag unter unseren Versuchsbedingungen zwischen 0,26 und $0,0076 \% / \mathrm{cm}^{2}$. Das Verhältnis von abgelagertem Acetaldehyd zu abgelagertem Solanesol betrug im RFS-Modul 0,96-1,96. Die Retention von Solanesol und Acetaldehyd pro Flächeneinheit in Mund und Bronchien lag in dieser Studie zwischen 0,095 und $0,0083 \% / \mathrm{cm}^{2}$. Die Retention pro Flächeneinheit der Alveolen lag weit unter der der beiden anderen Regionen $\left(0,0000063 \% / \mathrm{cm}^{2}\right)$. Das Verhältnis von zurückgehaltenem Acetaldehyd zu zurückgehaltenem Solanesol betrug 0,54-1,97. Aus diesen Ergebnissen wurde geschlussfolgert, dass das CULTEX ${ }^{\circledR}$ RFS-Modul im Hinblick auf die chemische Bilanz von Partikel- und Gas/Dampfphase die Zigarettenrauchexposition in vivo simulieren kann. Außerdem wurde festgestellt, dass die Exposition in diesem Modul die Retention in Mund und Bronchien wiedergeben konnte. [Beitr. Tabakforsch. Int. 27 (2016) 20-29]

\section{RESUME}

Dans le but d'évaluer le risque que présentent les agents chimiques en suspension, divers systèmes d'exposition directe in vitro ont été mis au point afin de répliquer l'exposition in vivo aux agents chimiques en suspension. Sachant que les cellules à l'interface air-liquide sont exposées à la fumée de cigarette, qui prend la forme d'un aérosol, dans les systèmes d'exposition directe, il est possible, à l'aide de ce dispositif, de reproduire les conditions d'exposition à la fumée de cigarette dans le système respiratoire humain. Cependant, il est difficile de savoir si la fumée de cigarette exposée dans un tel système est cohérente avec la fumée retenue dans le les voies respiratoires humaines. L'objet de la présente étude est d'éclaircir ce point à l'aide d'un système d'exposition directe récemment mis au point, le module à flux radial CULTEX $^{\circledR}$. A ces fins, le solanésol et l'acétaldéhyde ont été respectivement choisis en guise de représentants de la phase gaz/vapeur et des particules des constituants de la fumée; en outre, leur dépôt et leur équilibre, exprimés en unité de surface de la zone de culture cellulaire du module à flux radial, ont été mesurés (dosimétrie). Nous avons également mené des études concernant la rétention chez l'humain en vue d'une comparaison avec les données livrées par la dosimétrie. En comparant la fumée inhalée et la fumée expirée dans trois situations d'inhalation, nous avons estimé la rétention et l'équilibre régionaux de chaque représentant exprimés en unité de surface de plusieurs zones des voies respiratoires (à savoir, séparément, la cavité buccale, les bronches et les alvéoles). Le dépôt de solanésol et d'acétaldéhyde, exprimé en unité de surface de la zone de culture cellulaire du module à flux radial, diminue en fonction du débit de dilution et oscille entre 0,26 et $0,0076 \% / \mathrm{cm}^{2}$ dans nos conditions d'expérience. Le rapport entre l'acétaldéhyde déposé et le solanésol déposé s'étend de 0,96 à 1,96 dans le module à flux radial. La rétention du solanésol et de l'acétaldéhyde par unité de surface au niveau de la cavité buccale et des bronches s'étend de 0,095 à $0,0083 \% / \mathrm{cm}^{2}$ dans la présente étude. La rétention par unité de surface au niveau des alvéoles est bien plus faible que dans les deux autres zones $\left(0,0000063 \% / \mathrm{cm}^{2}\right)$. Le rapport entre l'acétaldéhyde retenu et le solanésol retenu s'étend de 0,54 à 1,97 . A la lumière de ces résultats, nous avons conclu que le module à flux radial CULTEX $^{\circledR}$ pouvait simuler l'exposition à la fumée de cigarette in vivo en termes d'équilibre chimique des particules exposées et de la phase gaz/vapeur. Nous avons également constaté que l'exposition dans ce module pouvait répliquer la rétention dans la cavité buccale et les bronches. [Beitr. Tabakforsch. Int. 27 (2016) 20-29]

\section{INTRODUCTION}

Cigarette smoke is a dynamic aerosol composed of more than 6000 chemical components (1-3). Approximately 5\% $(\mathrm{w} / \mathrm{w})$ of mainstream whole cigarette smoke are in the particulate phase, and the remaining $95 \%(\mathrm{w} / \mathrm{w})$ comprise the gas/vapor phase. To investigate the biological effects of cigarette smoke, traditionally, in vitro cell exposure experiments have been conducted using extracts of the particulate phase in dimethyl sulfoxide and the gas/vapor phase bubbled into aqueous solutions such as phosphatebuffered saline under submerged conditions (4-6). Over the last decade, however, a variety of in vitro direct exposure systems have been developed and used as alternative methods (7). Direct exposure systems generally consist of three functional steps: cigarette smoke generation, dilution, and exposure in a specially designed chamber. These systems do not require extraction or bubbling processes, and the cells at the air-liquid interface are immediately exposed to cigarette smoke after generation by the smoking machine. Therefore, it is also possible to expose cells to the water-insoluble fraction of mainstream cigarette smoke, which could not be evaluated using indirect extraction methods (8). As this direct exposure scenario can be adapted to the situation of cigarette smoke exposure in the respiratory system, some direct exposure systems have applied to in vitro bioassays to investigate the biological effects of cigarette smoke (9-12).

However, when discussing biological data obtained by direct in vitro exposure experiments for risk assessment, knowing the in vitro dose and comparison with an in vivo dose would be necessary (13). In some previous reports, the amount of cigarette smoke guided into the exposure chamber in direct exposure systems was calculated according to a formula $(14,15)$. However, since not all of the smoke guided into the exposure chamber will be deposited onto a cultured cell, it is desirable to obtain information of 
the amount of smoke actually deposited on the surface of the cultured cells to discuss dose-dependent reactions. Another group applied a quartz crystal microbalance in the VITROCELL $^{\circledR}$ module to measure the mass of cigarette smoke particles deposited on the culture surface and in parallel a gas analyzer to measure the concentration of carbon monoxide in cigarette smoke (16). ADAMSON et al. (17) measured the deposited mass of cigarette smoke particles in their original exposure chamber using a quartz crystal microbalance and compared the findings to previously reported data on cigarette smoke particle deposition in the human respiratory tract. This type of comparison is important for determining the actual tissue exposure.

In this report, we conducted a deposited dose measurement experiment (dosimetry tests) using the CULTEX ${ }^{\circledR}$ RFS module, which was applied to cigarette smoke and aerosolized particle exposure experiments $(18,19)$. This module permits the homogeneous distribution of aerosol particles demonstrated by computational fluid dynamics (20). We selected solanesol and acetaldehyde to simulate the particulate and gas/vapor phases of cigarette smoke, respectively, in our experiment. Solanesol is frequently used as a particulate phase marker of cigarette smoke because of its abundance and non-volatility $(21,22)$. We did not use nicotine as a particulate phase marker because nicotine is semi-volatile and because a small fraction of the nicotine in mainstream smoke can be present in the gas/vapor phase (23). Acetaldehyde is reported to exist in the gas/vapor phase of cigarette smoke $(24,25)$. We calculated the deposition and deposition balance of solanesol and acetaldehyde in this module. To clarify whether this in vitro data was consistent with the in vivo data, we also conducted a retention study, which is a common experiment for estimating the amount of cigarette smoke retained in the human airway by comparing the amounts of inhaled and exhaled cigarette smoke (26). For this purpose, the retention and retention balance of solanesol and acetaldehyde in the human respiratory tract were estimated in volunteers and compared to dosimetry data obtained from the in vitro exposure module.

\section{METHODS}

\section{In vitro dosimetry test}

\subsection{Smoke generation}

The experimental setup for the in vitro exposure experiments consisted of a VC 10 smoking robot (VITROCELL ${ }^{\circledR}$ Systems, Waldkirch, Germany) a dilution system, and a CULTEX $^{\circledR}$ RFS module (CULTEX ${ }^{\circledR}$ Laboratories, Hannover, Germany) as depicted in Figure 1. The Kentucky Reference Cigarette 3R4F (University of Kentucky, Lexington, $\mathrm{KY}, \mathrm{USA})$, conditioned at $22 \pm 2{ }^{\circ} \mathrm{C}$ and $60 \pm$ $5 \%$ relative humidity for $48 \mathrm{~h}$ before use, was smoked in accordance with the International Organization for Standardization (ISO: $35-\mathrm{mL}$ puffs of $2 \mathrm{~s}$ in duration every $\mathrm{min}$ ) (27) and Health Canada Intensive (HCI: $55-\mathrm{mL}$ puffs of $2 \mathrm{~s}$ in duration every $30 \mathrm{~s}$ ) regimens (28) in serial-asynchron mode. In one smoking run, eight cigarettes were simultaneously smoked under the ISO smoking condition and four cigarettes were simultaneously smoked under the HCI smoking condition.

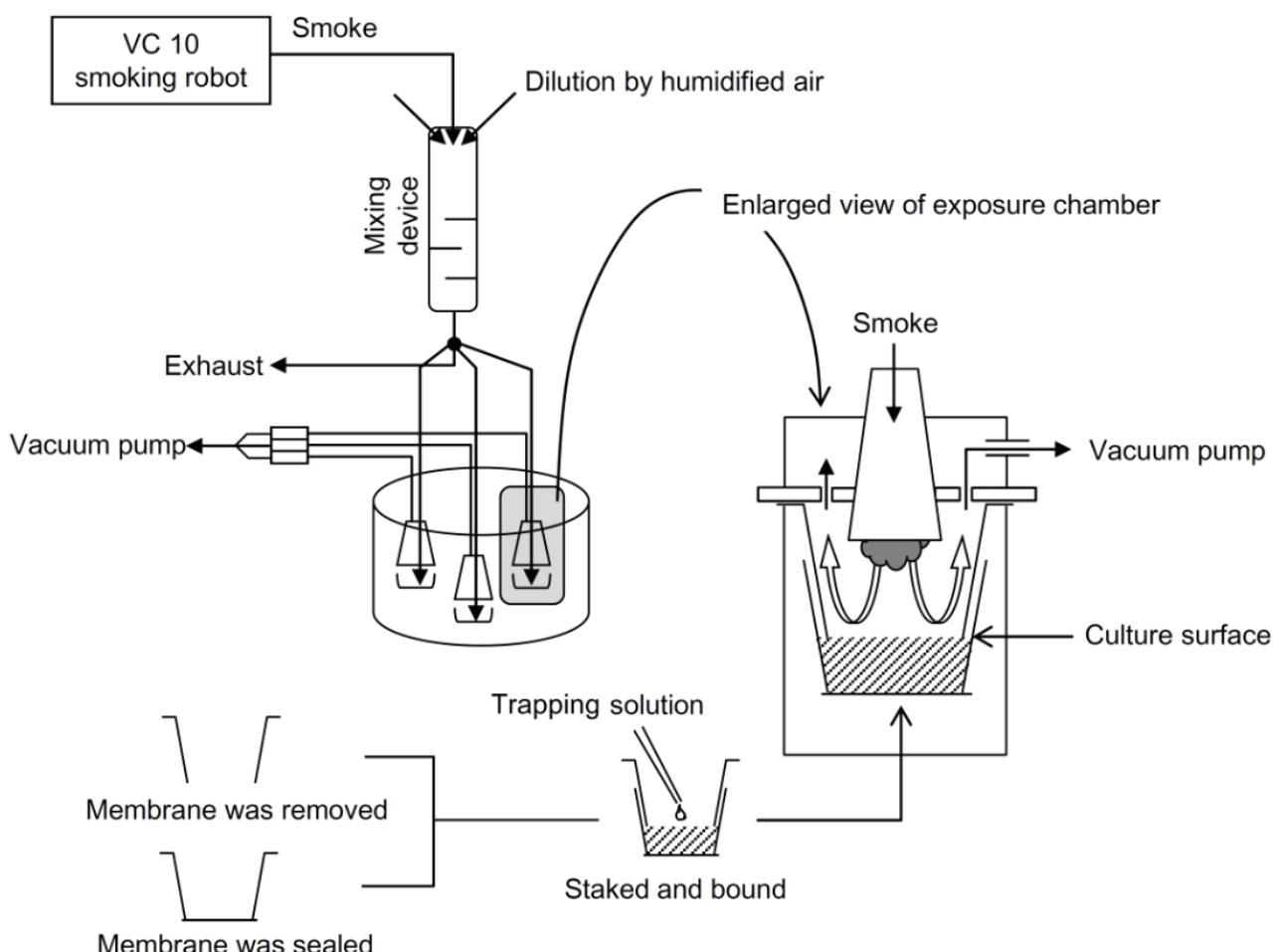

Figure 1. Schematic setup for the in vitro dosimetry test. 
Most of the experiments were conducted using single smoking run. A number of smoking runs were conducted when the solanesol concentrations were determined by HPLC. Two ISO smoking runs were performed using a dilution flow rate of $4 \mathrm{~L} / \mathrm{min}$, three at a dilution flow rate of $6 \mathrm{~L} / \mathrm{min}$, and six at a dilution flow rate of $8 \mathrm{~L} / \mathrm{min}$. Two $\mathrm{HCI}$ smoking runs were performed using a dilution flow rate of $4 \mathrm{~L} / \mathrm{min}$, three at a dilution flow rate of $6 \mathrm{~L} / \mathrm{min}$, and five at a dilution flow rate of $8 \mathrm{~L} / \mathrm{min}$. The cigarette smoke that was generated by the smoking robot was released into a mixing device in $2.8 \mathrm{~s}$ exhaust, and was diluted with humidified clean air (more than $90 \%$ relative humidity). For humidification of dilution air, clean air was bubbled through water in an impinger maintained at $37^{\circ} \mathrm{C}$. Diluted smoke was introduced into RFS module and guided into the exposure chamber $(5 \mathrm{~mL} / \mathrm{min})$ using a vacuum pump.

\subsection{Collection of chemicals in mainstream cigarette smoke}

In mainstream cigarette smoke, solanesol was trapped using 44-mm Cambridge filter pads (Borgwaldt KC, Hamburg, Germany) inserted between the cigarette ports and the syringe. Solanesol was extracted from the filter pads by methanol. The extract was diluted with methanol and filtered with DISMIC-13HP (pore size $0.2 \mu \mathrm{m}$; Advantec, Tokyo, Japan) for HPLC analysis. Acetaldehyde in the mainstream cigarette smoke was trapped by two or three 2,4-dinitrophenylhydrazine (DNPH) active gas tubes (Yotsubishi Corporation, Tokyo, Japan) connected in-line, and acetaldehyde trapped in each tube was eluted with $40 \mathrm{~mL}$ of a DNPH/acetonitrile/ $\mathrm{H}_{2} \mathrm{O}$ mixed solvent (composition: $4.76 \mathrm{~g}$ of DNPH diluted to $500 \mathrm{~mL}$ by acetonitrile, $2.8 \mathrm{~mL}$ of perchloric acid, and $\mathrm{H}_{2} \mathrm{O}$ to a final volume of $1 \mathrm{~L})$ for analysis. The eluted solvent was stabilized in 1.5 parts of 2-Amino-2-(hydroxymethyl)-1,3-propanediol (trizma base) solution (composition: $2 \mathrm{~g}$ of trizma diluted to $200 \mathrm{~mL}$ by $\mathrm{H}_{2} \mathrm{O}$ and acetonitrile to a final volume of $1 \mathrm{~L}$ ) for HPLC analysis. The amounts of solanesol and acetaldehyde in the mainstream smoke were determined three times, and the mean and standard deviation (SD) were calculated.

\subsection{Collection of cigarette smoke deposited onto the culture surface}

To collect smoke, cell culture inserts were modified as shown in Figure 1. We staked and bound two culture inserts (Becton Dickinson, Franklin Lakes, NJ, USA). The bottom membrane of the upper insert was removed and the bottom membrane of the lower insert was sealed to create a space for the trapping solution $(1.4 \mathrm{~mL})$. The surface height of the solution was adjusted to the removed membrane position. Solanesol was trapped by $1.4 \mathrm{~mL}$ of methanol and analyzed by HPLC. Acetaldehyde was trapped by $1.4 \mathrm{~mL}$ of $\mathrm{H}_{2} \mathrm{O}$ and derivatized using equal parts of a DNPH/perchloric acid/acetonitrile mixed solvent (composition: $9.52 \mathrm{~g}$ of DNPH, $5.6 \mathrm{~mL}$ of perchloric acid, and acetonitrile to a final volume of $1 \mathrm{~L}$ ). Derivatized acetaldehyde (acetaldehyde hydrazone) was filtered and stabilized in 1.5 parts of the trizma base solution for HPLC analysis. The experiment was repeated three times for each experimental condition, and the mean value of the three inserts in each experiment was used to calculate the mean and SD of each experimental condition. The deposition of solanesol and acetaldehyde was calculated as follows:

Deposition $(\%)=100 \times$ amount trapped in the solution / amount generated by smoking robot. Deposition per unit surface area $\left(\% / \mathrm{cm}^{2}\right)=$ Deposition $/$ surface area of insert $\operatorname{cup}\left(0.9 \mathrm{~cm}^{2}\right)$.

\section{Human retention study}

\subsection{Study design}

This study was conducted in compliance with the principles of the Declaration of Helsinki (2008). Seventeen male smokers who were employees of Japan Tobacco Inc. were provided with details of all of the procedures used in the study prior to providing written informed consent to participate. Each subject was made aware they were free to leave the study at any time.

All cigarettes used in this study were 1-mg "tar" commercial products made in Japan. The volunteers smoked three cigarettes using three different inhalation patterns. Each cigarette was smoked until a point approximately $3 \mathrm{~mm}$ from the tipping paper was reached, and the cigarette filter was pulled from the remaining cigarette butt after smoking. The amount of smoke components inhaled by each subject was estimated using the amount of solanesol deposited in this filter. For the first cigarette, each subject took a puff every minute and held the smoke in his mouth for $2 \mathrm{~s}$ before exhalation (mouth hold). For the second cigarette, each subject took a puff every minute, held the smoke in his mouth for $2 \mathrm{~s}$, and inhaled $150 \mathrm{~mL}$ of air stored in a sampling bag (Omi Odor Air Service, Shiga, Japan) before exhalation ( $150 \mathrm{~mL}$ inhalation). This inhalation control was based on previous reports $(29,30)$. For the third cigarette, each subject took a puff every minute, held the smoke in his mouth for $2 \mathrm{~s}$, and inhaled normally before exhalation (normal inhalation). Exhaled cigarette smoke was collected using 92-mm Cambridge filter pads and sampling bags. Solanesol was extracted from the filter pads by methanol. The extract was diluted and filtered before HPLC analysis. Cigarette smoke exhaled into the sampling bag was sucked through DNPH active gas tubes to collect acetaldehyde and eluted using $40 \mathrm{~mL}$ of the $\mathrm{DNPH} /$ acetonitrile/ $\mathrm{H}_{2} \mathrm{O}$ mixed solvent. The eluted solvent was stabilized in 1.5 parts of the trizma base solution for HPLC analysis.

\subsection{Estimation of the amount of inhaled smoke}

Good relationships between the amount of solanesol deposited in the cigarette filter and that of the delivered mainstream smoke constituents were previously reported $(31,32)$. We used these relationships to estimate the amount of inhaled cigarette smoke constituents. The commercial cigarettes were smoked under six different smoking conditions (Table 1) using the VC 10 smoking robot. Mainstream solanesol collected by 44-mm Cambridge filter pads and acetaldehyde collected by DNPH active gas tubes were analyzed using HPLC. The experiment was repeated three times for each smoking condition. The cigarette filter was removed from the remaining cigarette butt, and solanesol deposited in the filter was 
Table 1. Machine smoking conditions under which the cigarettes used in retention study were smoked.

\begin{tabular}{c|c|c}
\hline $\begin{array}{l}\text { Puff volume } \\
(\mathrm{mL})\end{array}$ & $\begin{array}{c}\text { Puff duration } \\
(\mathrm{s})\end{array}$ & $\begin{array}{c}\text { Puff interval } \\
(\mathrm{s})\end{array}$ \\
\hline 30 & 2 & 30,60 \\
70 & 2 & 30,60 \\
120 & 2 & 30,60 \\
\hline
\end{tabular}

extracted by methanol and analyzed by HPLC simultaneously. The relationship between the mainstream delivery for each constituent and the solanesol content in the cigarette filter under different smoking conditions was analyzed using linear regression. The amount of smoke components each subject inhaled was estimated by this linear regression.

\subsection{Calculation of regional retention}

The respiratory retention of solanesol and acetaldehyde for each inhalation pattern was calculated as follows: Retention $(\%)=100 \times($ amount inhaled - amount exhaled $) /$ amount inhaled. We assumed cigarette smoke was retained in the mouth under the mouth hold condition. The mean (and SD) retention for seventeen volunteers in each inhalation pattern was calculated, and the mean was used to calculate regional retention as shown below. As the average volume of dead space originating in an upper airway where no exchange is possible between blood and breath has been reported as $150 \mathrm{~mL}$ in the literature (33), we presumed cigarette smoke was mainly retained in the mouth and bronchi (dead space) under the $150-\mathrm{mL}$ inhalation condition. With this presumption, we calculated retention in the bronchial region as the difference between retention under the $150-\mathrm{mL}$ inhalation condition and that under the mouth hold condition. We also calculated retention in the alveoli as the difference between retention under the normal inhalation condition and that under the $150-\mathrm{mL}$ inhalation condition. The range of normal inhalation volumes was reported to be more than $150 \mathrm{~mL}(30,32)$. As we had set the dead space volume to $150 \mathrm{~mL}$ we assumed that cigarette smoke was retained in the alveoli when subjects inhaled over $150 \mathrm{~mL}$.

\section{HPLC conditions}

An Agilent 1100 series HPLC system (Agilent Technologies, Santa Clara, CA, USA) was used for HPLC analysis. Solanesol analysis was performed on the basis of CORESTA Recommended Method No. 52 (34). For solanesol analysis, an Xbridge Shield RP18 $(250 \times 4.6 \mathrm{~mm}$, $5 \mu \mathrm{m}$; Waters Corporation, Milford, MA, USA) was used. The sample injection volume was $100 \mu \mathrm{L}$. The mobile phase was 5\% methanol in acetonitrile. The HPLC separation required a $1.0 \mathrm{~mL} / \mathrm{min}$ flow rate. The detection wavelength was $205 \mathrm{~nm}$. Acetaldehyde analysis was performed according to a previously reported method (35). For acetaldehyde analysis, LiChrospher 100 RP-18e $(250 \times 4 \mathrm{~mm}, 5 \mu \mathrm{m}$; Merck Millipore, Darmstadt, Germany) was used. The sample injection volume was $20 \mu \mathrm{L}$. The HPLC separation required a $1.5 \mathrm{~mL} / \mathrm{min}$ flow rate and a gradient to elute the analytes within $25 \mathrm{~min}$. The settings were as follows: $0-8 \mathrm{~min}, 70 \% / 30 \%$ mobile phase $\mathrm{A} / \mathrm{B}$; 8-20 $\mathrm{min}, 47 \% / 53 \%$ mobile phase $\mathrm{A} / \mathrm{B} ; 20-27 \mathrm{~min}$, $0 \% / 100 \%$ mobile phase A/B. Mobile phase A was $59 \%$ water, $30 \%$ acetonitrile, $10 \%$ tetrahydrofuran, and $1 \%$ 2-propanol. Mobile phase B was $65 \%$ acetonitrile, $33 \%$ water, $1 \%$ tetrahydrofuran, and $1 \%$ 2-propanol. The detection wavelength was $365 \mathrm{~nm}$. The HPLC conditions that were used made it possible to determine other carbonyl compounds, in addition to acetaldehyde (35). The other carbonyl compounds were found at low concentrations, and they were not detectable under some experimental conditions, so we will only discuss the acetaldehyde data.

\section{RESULTS}

\section{In vitro dosimetry test}

\subsection{Analysis of 3R4F mainstream smoke generated by the smoking machine}

Solanesol and acetaldehyde in the mainstream 3R4F smoke under the ISO and HCI smoking conditions were analyzed using HPLC. The amounts of solanesol and acetaldehyde in mainstream smoke were approximately 2.9-fold higher under the HCI smoking condition than under the ISO smoking condition (Table 2).

Table 2. The amount of solanesol and acetaldehyde in mainstream smoke of $3 R 4 F$.

\begin{tabular}{l|c|c}
\hline Smoking regimen & $\begin{array}{c}\text { Solanesol } \\
(\mu \mathrm{g} / \mathrm{cig})\end{array}$ & $\begin{array}{c}\text { Acetaldehyde } \\
(\mu \mathrm{g} / \mathrm{cig})\end{array}$ \\
\hline $\mathrm{ISO}$ & $260.1 \pm 11.1$ & $555.7 \pm 104.3$ \\
$\mathrm{HCl}$ & $755.7 \pm 35.4$ & $1619.2 \pm 143.2$ \\
\hline
\end{tabular}

${ }^{*}$ mean \pm S.D.

\subsection{Analysis of smoke deposited onto culture surfaces}

Cigarette smoke from 3R4F was exposed to the surface of trapping solution at various dilutions and analyzed by HPLC. The deposited masses of solanesol and acetaldehyde per cigarette decreased in accordance with the dilution rate (Figure 2). Corresponding to the increased mainstream mass of solanesol per cigarette under the HCI smoking regimen (Table 2), the deposited mass of solanesol per cigarette increased by approximately more than 2-fold under the HCI smoking regimen compared with the findings under the ISO smoking regimen at the same dilution (Figure 2). Similar findings were recorded for acetaldehyde. For further analysis, the deposition (\%) was calculated by dividing the deposited solanesol or acetaldehyde mass (Figure 2) by each generated mass (Table 2). The deposition per bottom area of the insert cup $\left(\% / \mathrm{cm}^{2}\right)$ is presented in Tables 3 and 4. When deposition was expressed as a percentage of the generated smoke instead of the deposited mass ( $\mu \mathrm{g} / \mathrm{cig}$, Figure 2), little difference was noted between the deposition of each constituent under the $\mathrm{HCI}$ and ISO conditions at the same dilution. 

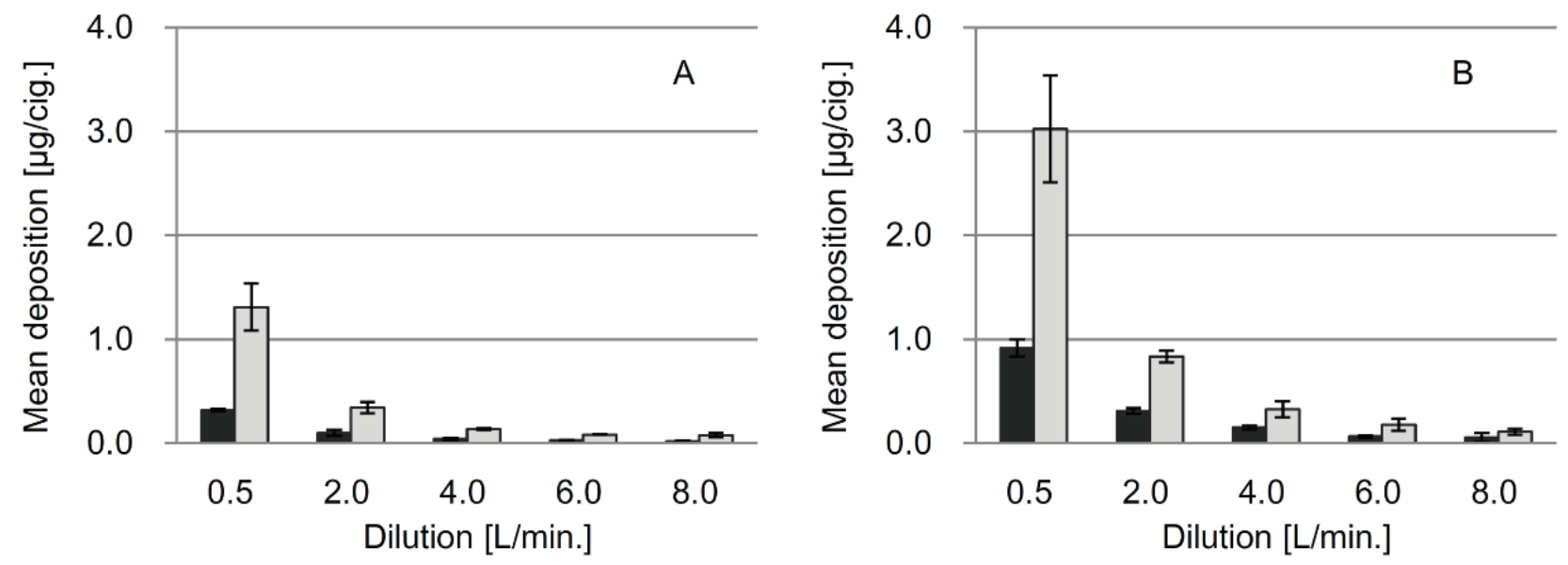

Figure 2. Results of the dosimetry tests under the (A) ISO and (B) HCI smoking regimens. The deposited masses of solanesol (black bar) and acetaldehyde (gray bar) on the culture surface were analyzed by HPLC. To present the deposited mass per cigarette, the measured mass was divided by the number of cigarette smoked for each exposure condition. The results are presented as the mean and S.D. $(n=3$ for each condition).

Table 3. Deposition per unit area in CULTEX ${ }^{\circledR}$ RFS module under ISO smoking regimen.

\begin{tabular}{l|c|c|c}
\hline $\begin{array}{l}\text { Dilution } \\
(\mathrm{L} / \mathrm{min})\end{array}$ & $\begin{array}{c}\text { Solanesol } \\
\left(\% / \mathrm{cm}^{2}\right)\end{array}$ & $\begin{array}{c}\text { Acetaldehyde } \\
\left(\% / \mathrm{cm}^{2}\right)\end{array}$ & $\begin{array}{c}\text { Acetaldehyde } / \text { solanesol } \\
\text { balance }\end{array}$ \\
\hline 0.5 & mean \pm S.D. & $0.2621 \pm 0.0457$ & 1.93 \\
2.0 & $0.1361 \pm 0.0055$ & $0.0683 \pm 0.0107$ & 1.62 \\
4.0 & $0.0422 \pm 0.0118$ & $0.0270 \pm 0.0012$ & 1.52 \\
6.0 & $0.0178 \pm 0.0042$ & $0.0165 \pm 0.0004$ & 1.55 \\
8.8 & $0.0106 \pm 0.0029$ & $0.0157 \pm 0.0044$ & 1.96 \\
\hline
\end{tabular}

Mainstream generation is taken as $100 \%$.

Acetaldehyde / solanesol balance of mainstream smoke is taken as 1.00 .

Surface area of insert cup is $0.9 \mathrm{~cm}^{2}$.

Table 4. Deposition per unit area in CULTEX ${ }^{\circledR}$ RFS module under $\mathrm{HCl}$ smoking regimen.

\begin{tabular}{l|c|c|c}
\hline $\begin{array}{c}\text { Dilution } \\
(\mathrm{L} / \mathrm{min})\end{array}$ & $\begin{array}{c}\text { Solanesol } \\
\left(\% / \mathrm{cm}^{2}\right)\end{array}$ & $\begin{array}{c}\text { Acetaldehyde } \\
\left(\% / \mathrm{cm}^{2}\right) \\
\text { mean } \pm \text { S.D. }\end{array}$ & $\begin{array}{c}\text { Acetaldehyde / solanesol } \\
\text { balance }\end{array}$ \\
\hline & & mean \pm S.D. & 1.54 \\
0.5 & $0.1348 \pm 0.0120$ & $0.2074 \pm 0.0352$ & 1.26 \\
4.0 & $0.0455 \pm 0.0040$ & $0.0572 \pm 0.0038$ & 1.01 \\
6.0 & $0.0220 \pm 0.0026$ & $0.0223 \pm 0.0052$ & 1.30 \\
8.8 & $0.0094 \pm 0.0018$ & $0.0122 \pm 0.0039$ & 0.96 \\
\hline
\end{tabular}

Mainstream generation is taken as $100 \%$.

Acetaldehyde / solanesol balance of mainstream smoke is taken as 1.00 .

Surface area of insert cup is $0.9 \mathrm{~cm}^{2}$.

Deposition balance was also calculated by dividing the deposition of acetaldehyde by that of solanesol. The deposition balance was in the range of 1-2-fold in our experimental conditions, and acetaldehyde tended to be efficiently deposited, excluding the $8 \mathrm{~L} / \mathrm{min} \mathrm{HCI}$ condition. 


\section{Human retention study}

\subsection{Preparation of calculating formula for inhaled smoke estimation}

Commercially available 1-mg "tar" cigarettes were used for the solanesol and acetaldehyde retention study. The relationships between the mainstream deliveries for each constituent and the amount of solanesol deposited in the cigarette filter are presented in Figure 3. A good correlation is shown for each constituent, with the coefficients of determination $\left(R^{2}\right)$ being approximately 0.9 . The amount of solanesol in the filters of cigarette butts collected from the human study was analyzed to estimate the amount of smoke inhaled by each subject using the obtained formula.

\subsection{Retention study}

Subjects smoked cigarettes under three different conditions (mouth hold, $150 \mathrm{~mL}$ inhalation, and normal inhalation), and exhaled smoke was collected by $92-\mathrm{mm}$ Cambridge filter pads and sampling bags for analysis. From the difference between inhaled smoke estimated by the amount of solanesol deposited in the cigarette filter (Figure 3) and exhaled smoke, the percentages of retained cigarette smoke constituents were calculated for each inhalation condition (Figure 4). The retention of solanesol and acetaldehyde increased according to the inhalation depth, and the retention of acetaldehyde was higher than that of solanesol under each inhalation condition. The retention in each respiratory area (mouth, bronchi, and alveoli) was calculated by comparing the retention for each inhalation pattern (Table 5). The retention of solanesol was comparable among the respiratory areas (ranging from 17.3 to $22.6 \%$ ), whereas that of acetaldehyde in the respiratory areas was higher in the upper respiratory tract than that in the lower respiratory tract (ranging from 9.3 to $44.4 \%$ ). The retention per unit area was calculated using the surface area of each respiratory region (36). The retention of solanesol and acetaldehyde per unit area was higher in the upper respiratory tract than in the lower respiratory tract. The ratio of retained acetaldehyde to retained solanesol ranged from 0.54 to 1.97 (Table 5).

\section{DISCUSSION}

In this report, we conducted dosimetric tests to clarify the deposition of cigarette smoke using the CULTEX ${ }^{\circledR}$ RFS module. Some previous reports presented the results of dosimetric tests using other exposure modules. In those reports, a quartz crystal microbalance was applied to measure the deposited mass of the particulate phase $(20,21)$. THORNE et al. (20) also applied a gas analyzer to the Vitrocell ${ }^{\circledR}$ module to measure the concentration of carbon monoxide in cigarette smoke. We conducted dosimetric studies with a different method (37). The amounts of representative chemicals in the particulate phase and the gas/vapor phase that were deposited were measured. The advantages of using this method were that we could measure the amounts of the components that were deposited onto cells growing at the air-liquid interface and that we could assess the amounts of components of both the particulate phase and the gas/vapor phase that were deposited in the module. We conducted dosimetry tests with the 3R4F reference cigarette. There was little difference between the deposition of each component under ISO and HCI smoking regimens at the same dilution (Tables 3 and 4). Considering that the mainstream production of solanesol and acetaldehyde under the HCI smoking regimen is approximately 2.9-fold higher than that under the ISO smoking regimen (Table 2), this might indicate that the total amount of generated smoke constituents have little effect on the deposition. The ratio of deposited acetaldehyde to deposited solanesol was in the range of 1-2 in our experimental conditions (Tables 3 and 4). This suggests that the deposition of acetaldehyde is higher than that of solanesol.

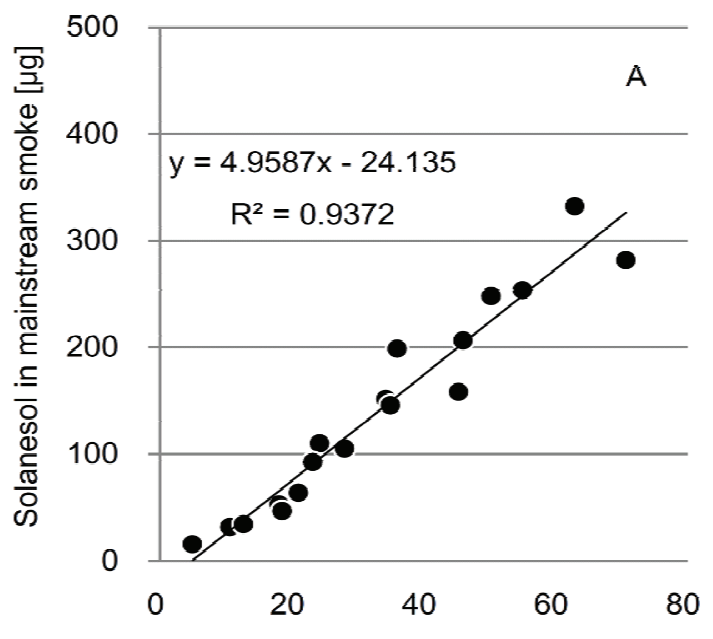

Solanesol deposited in cigarette filter $[\mu \mathrm{g}]$

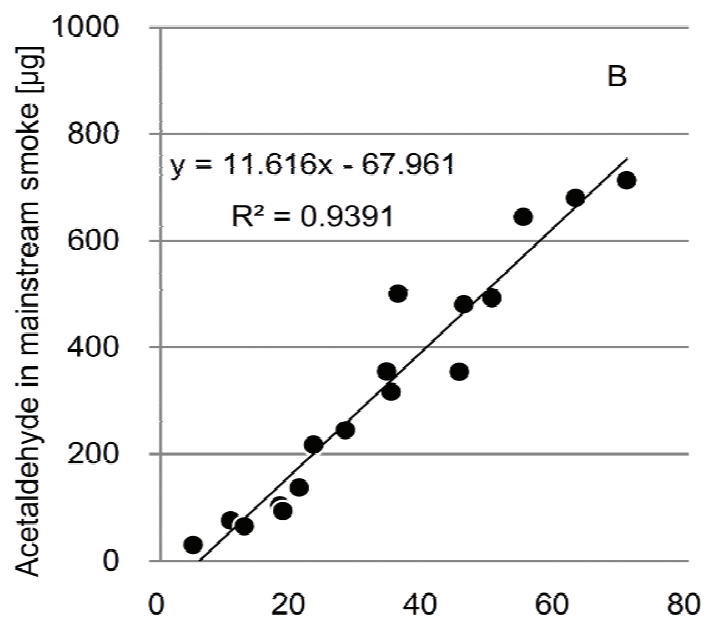

Solanesol deposited in cigarette filter $[\mu \mathrm{g}]$

Figure 3. Regression line between the levels of $(A)$ solanesol and $(B)$ acetaldehyde in the mainstream smoke of cigarettes used in the retention study and the level of solanesol in the cigarette filter. 


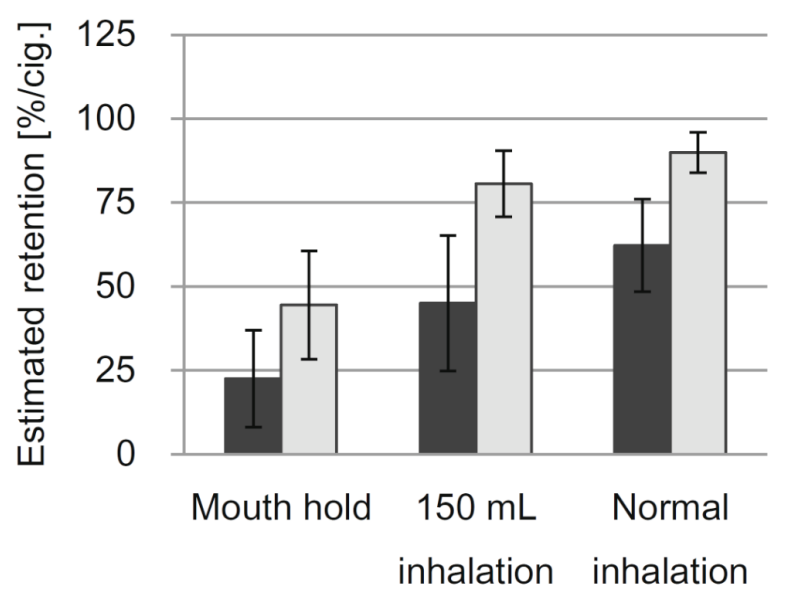

Smoking patterns

Figure 4. Estimated respiratory retention of solanesol (black bar) and acetaldehyde (gray bar) in adult volunteers who smoked cigarettes under three different inhalation conditions. The results are presented as the mean and S.D. $(n=17$ for each condition).

The diffusion coefficient is a factor that affects chemical deposition of smoke in exposure modules. The diffusion coefficient of acetaldehyde is $1.24 \times 10^{-1} \mathrm{~cm}^{2} / \mathrm{s}(38)$, and that of $0.1-\mu \mathrm{m}$ particles is $6.8 \times 10^{-6} \mathrm{~cm}^{2} / \mathrm{s}(39)$. As acetaldehyde has a higher diffusion coefficient than particulate phase chemicals, it is believed to reach the culture surface more efficiently in the exposure chamber than solanesol.

We also conducted retention studies for comparisons with the in vitro deposition data. Seventeen male adult smokers smoked 1-mg "tar" commercial cigarettes under three inhalation patterns: mouth hold, $150 \mathrm{~mL}$ inhalation, and normal inhalation. The retention of solanesol and acetaldehyde was calculated by comparing the inhaled dose to the exhaled dose. The retention of solanesol was approximately $60 \%$ under the normal inhalation condition, and this value increased as the inhalation depth increased (Figure 4) as previously reported $(29,30)$. Approximately $90 \%$ of inhaled acetaldehyde was retained under the normal inhalation condition (Figure 4), and this value is consistent with previous findings $(32,35)$. We calculated the regional retention by comparing the results under the three different inhalation conditions. As the surface area of alveoli is large, the retention of solanesol and acetaldehyde per unit area was markedly lower in alveoli than in the other two regions (Table 5). The ratio of retained acetaldehyde to retained solanesol ranged from 0.54 to 1.97 in our experimental conditions, and the value was higher in the upper respiratory tract (mouth) than in the lower respiratory tract (bronchi and alveoli) because acetaldehyde was well retained in the upper respiratory tract (Table 5). This behavior of acetaldehyde in the upper respiratory tract is consistent with the data obtained in a recent simulation study (38). We calculated the regional retention based on the hypothesis that retention was restricted in the mouth and bronchi under the $150-\mathrm{mL}$ inhalation condition. However, the hypothesis did not account for individual variation, and we could not apply any personal corrections. In addition, cigarette smoke is not equally retained over the entire surface of the respiratory tract, and there must be deposition hot spots at which inhaled cigarette smoke is retained better compared to other regions $(40,41)$. Thus, our estimation of regional retention may include some limitations. Nevertheless, as an approximation, we calculated the regional retention by comparing the results obtained for the three inhalation patterns. As a model of bronchial epithelium, normal human bronchial cells cultured under the air-liquid interface condition have been applied to direct cigarette smoke exposure experiments recently $(10,42,43)$. A549 human alveolar epithelial cells cultured under the air-liquid interface condition have also been used as a model of alveolar epithelium in direct exposure experiments $(15,44)$. Thus, our regional retention data could be helpful when discussing the results of direct smoke exposure experiments with these models on the point of actual tissue dose.

In our experiments, the deposition of solanesol and acetaldehyde per unit surface area in the CULTEX ${ }^{\circledR}$ RFS module (Tables 3 and 4 ) were sufficient to achieve comparable retention per unit surface area in the mouth and bronchi (Table 5). Because the retention per unit surface area in alveoli was markedly lower, it was necessary to use a higher dilution than applied in this experiment to reproduce the efficiency in vitro. The ratio of acetaldehyde to solanesol deposited in the CULTEX ${ }^{\circledR}$ RFS module was consistent with the retention balance of solanesol and acetaldehyde in the human respiratory tract.

Table 5. "Retention" and "retention per unit surface area" in each region of the respiratory tract.

\begin{tabular}{|c|c|c|c|c|c|c|}
\hline \multirow{2}{*}{ Region } & \multirow{2}{*}{$\begin{array}{l}\text { Area } \\
\left(\mathrm{cm}^{2}\right)\end{array}$} & \multicolumn{2}{|c|}{ Solanesol } & \multicolumn{2}{|c|}{ Acetaldehyde } & \multirow{2}{*}{$\begin{array}{c}\text { Acetaldehyde / solanesol } \\
\text { balance }\end{array}$} \\
\hline & & $(\%)$ & $\left(\% / \mathrm{cm}^{2}\right)$ & $(\%)$ & $\left(\% / \mathrm{cm}^{2}\right)$ & \\
\hline Mouth & 470 & 22.6 & 0.0480 & 44.4 & 0.0945 & 1.97 \\
\hline Bronchi & 2,690 & 22.4 & 0.00832 & 36.2 & 0.0135 & 1.62 \\
\hline Alveoli & $1,475,000$ & 17.3 & 0.0000117 & 9.3 & 0.0000063 & 0.54 \\
\hline
\end{tabular}

Mainstream generation is taken as $100 \%$.

Acetaldehyde / solanesol balance of mainstream smoke is taken as 1.00 .

*: ICRP Publication 66 (36). 
From these results, we concluded that the CULTEX ${ }^{\circledR}$ RFS module is a reliable direct exposure system for simulating in vivo cigarette smoke exposure in terms of the exposed particulate and gas/vapor phase chemical balance. We also found that the exposure efficiency in this module could replicate the retention efficiency in the mouth and bronchi. Future work using this direct exposure module will be helpful for understanding the biological effect of cigarette smoke on the human respiratory system.

\section{ACKNOWLEDGEMENTS}

The authors would like to thank Drs. Tomoki Nishino and Hitoshi Fujimoto for their time and efforts in reviewing this article.

\section{REFERENCES}

1. Church, D.F. and W.A. Pryor: Free-Radical Chemistry of Cigarette Smoke and its Toxicological Implications; Environ. Health Persp. 64 (1985) 111-126.

2. Hoffmann, D. and E.L. Wynder: Chemical Constituents and Bioactivity of Tobacco Smoke; in: Tobacco: A Major Health Hazard, edited by D.G. Zardidze and R. Peto, IARC, Lyon, France, IARC Sci. Publ. No. 74 (1986) 145-165.

3. Rodgman, A. and T.A. Perfetti: The Chemical Components of Tobacco and Tobacco Smoke, Second Edition; CRC press, Boca Raton, FL, USA, 2013.

4. Mizusaki, S., T. Takashima, and K. Tomaru: Factors Affecting Mutagenic Activity of Cigarette Smoke Condensate in Salmonella Typhimurium TA 1538; Mutat. Res. 48 (1977) 29-36.

5. Nakayama, T., M. Kaneko, M. Kodama, and C. Nagata: Cigarette Smoke Induces DNA Singlestrand Breaks in Human Cells; Nature 314 (1985) 462-464.

6. Andreoli, C., D. Gigante, and A. Nunziata: A Review of In Vitro Methods to Assess the Biological Activity of Tobacco Smoke With the Aim of Reducing the Toxicology of Smoke; Toxicol. In Vitro 17 (2003) 587-594

7. Thorne, D. and J. Adamson: A Review of In Vitro Cigarette Smoke Exposure Systems; Exp. Toxicol. Pathol. 65 (2013) 1183-1193.

8. Nara, H., Y. Fukano, T. Nishino, and M. Aufderheide: Detection of the Cytotoxicity of Water-Insoluble Fraction of Cigarette Smoke by Direct Exposure to Cultured Cells at an Air-Liquid Interface; Exp. Toxicol. Pathol. 65 (2013) 683-688.

9. Fukano, Y., M. Ogura, K. Eguchi, M. Shibagaki, and M. Suzuki: Modified Procedure of a Direct In Vitro Exposure System for Mammalian Cells to Whole Cigarette Smoke; Exp. Toxicol. Pathol. 55 (2004) 317-323.

10. Maunders, H., S. Patwardhan, J. Phillips, A. Clack, and A. Richter: Human Bronchial Epithelial Cell Transcriptome: Gene Expression Changes Following Acute Exposure to Whole Cigarette Smoke In Vitro; Am. J. Physiol. Lung Cell Mol. Physiol. 292 (2007) 1248-1256.
11. Aufderheide, M. and H. Gressmann: Mutagenicity of Native Cigarette Mainstream Smoke and its Gas Vapour Phase by Use of Different Tester Strains and Cigarettes in a Modified Ames Assay; Mutat. Res. 656 (2008) 82-87.

12. Scian, M.J., M.J. Oldham, D.B. Kane, J.S. Edmiston, and W.J. McKinney: Characterization of a Whole Smoke In Vitro Exposure System (Burghart Mimic Smoker-01); Inhal. Toxicol. 21 (2009) 234-243.

13. Paur, H.R., F.R. Cassee, J. Teeguarden, H. Fissan, S. Diabate, M. Aufderheide, W.G. Kreyling, O. Hänninen, G. Kasper, M. Riediker, B. RothenRutishauser, and O. Schmid: In-Vitro Cell Exposure Studies for the Assessment of Nanoparticle Toxicity in the Lung-A Dialog Between Aerosol Science and Biology; J. Aerosol Sci. 42 (2011) 668-692.

14. Okuwa, K., M. Tanaka, Y. Fukano, H. Nara, Y. Nishijima, and T. Nishino: In Vitro Micronucleus Assay for Cigarette Smoke Using a Whole Smoke Exposure System: A Comparison of Smoking Regimens; Exp. Toxicol. Pathol. 62 (2010) 433-440.

15. Weber, S., M. Hebestreit, T. Wilms, L.L. Conroy, and G. Rodrigo: Comet Assay and Air-Liquid Interface Exposure System: A New Combination to Evaluate Genotoxic Effects of Cigarette Whole Smoke in Human Lung Cell Lines; Toxicol. In Vitro 27 (2013) 1987-1991.

16. Thorne, D., J. Kilford, R. Payne, J. Adamson, K. Scott, A. Dalrymple, C. Meredith, and D. Dillon: Characterisation of a Vitrocell ${ }^{\circledR}$ VC 10 In Vitro Smoke Exposure System Using Dose Tools and Biological Analysis; Chem. Cent. J. 7 (2013) 146.

17. Adamson, J., S. Hughes, D. Azzopardi, J. McAughey, and M.D. Gaça: Real-Time Assessment of Cigarette Smoke Particle Deposition In Vitro; Chem. Cent. J. 6 (2012) 98 .

18. Aufderheide, M., S. Scheffler, N. Möhle, B. Halter, and D. Hochrainer: Analytical In Vitro Approach for Studying Cyto- and Genotoxic Effects of Particulate Airborne Material; Anal. Bioanal. Chem. 401 (2011) 3213-3220.

19. Steinritz, D., N. Möhle, C. Pohl, M. Papritz, B. Stenger, A. Schmidt, C.J. Kirkpatrick, H. Thiermann, R. Vogel, S. Hoffmann, and M. Aufderheide: Use of the Cultex ${ }^{\circledR}$ Radial Flow System as an In Vitro Exposure Method to Assess Acute Pulmonary Toxicity of Fine Dusts and Nanoparticles With Special Focus on the Intra- and Inter-Laboratory Reproducibility; Chem. Biol. Interact. 206 (2013) 479-490.

20. Aufderheide, M., B. Halter, N. Möhle, and D. Hochrainer: The CULTEX RFS: A Comprehensive Technical Approach for the In Vitro Exposure of Airway Epithelial Cells to the Particulate Matter at the Air-Liquid Interface; Biomed Res. Int. (2013) DOI: 10.1155/2013/734137 Epub 2013 Feb 7.

21. Tang, H., G. Richards, C.L. Benner, J.P. Tuominen, M.L. Lee, E.A. Lewis, L.D. Hansen, and D.J. Eatough: Solanesol: A Tracer for Environmental Tobacco Smoke Particles; Environ. Sci. Technol. 24 (1990) 848-852.

22. Benowitz, N.L.: Biomarkers of Environmental Tobacco Smoke Exposure; Environ. Health Perspect. 107 
Suppl. 2 (1999) 349-355.

23. Pankow, J.F.: A Consideration of the Role of Gas/ Particle Partitioning in the Deposition of Nicotine and Other Tobacco Smoke Compounds in the Respiratory Tract; Chem. Res. Toxicol. 14 (2001) 1465-1481.

24. Baker, R.R.: The Generation of Formaldehyde in Cigarettes -- Overview and Recent Experiments; Food Chem. Toxicol. 44 (2006) 1799-1822.

25. Adam, T., J. McAughey, C. McGrath, C. Mocker, and R. Zimmermann: Simultaneous On-Line Size and Chemical Analysis of Gas Phase and Particulate Phase of Cigarette Mainstream Smoke; Anal. Bioanal. Chem. 394 (2009) 1193-1203.

26. Baker, R.R. and M. Dixon: The Retention of Tobacco Smoke Constituents in the Human Respiratory Tract; Inhal. Toxicol. 18 (2006) 255-294.

27. International Organization for Standadarzation (ISO): ISO 3308:2012 - Routine Analytical Cigarette-Smoking Machine -- Definitions and Standard Conditions; ISO, Geneva, Switzerland, 2012.

28. Health Canada: Official Method T-115 - Determination of "Tar", Water, Nicotine and Carbon Monoxide in Mainstream Tobacco Smoke; Health Canada, Ottawa, Canada, 1999.

29. Armitage, A.K., M. Dixon, B.E. Frost, D.C. Mariner, and N.M. Sinclair: The Effect of Tobacco Blend Additives on the Retention of Nicotine and Solanesol in the Human Respiratory Tract and on Subsequent Plasma Nicotine Concentrations During Cigarette Smoking; Chem. Res. Toxicol. 17 (2004) 537-544.

30. Armitage, A.K., M. Dixon, B.E. Frost, D.C. Mariner, and N.M. Sinclair: The Effect of Inhalation Volume and Breath-Hold Duration on the Retention of Nicotine and Solanesol in the Human Respiratory Tract and on Subsequent Plasma Nicotine Concentrations During Cigarette Smoking; Beitr. Tabakforsch. Int. 21 (2004) 240-249.

31. Watson, C., J. McCraw, G. Polzin, D. Ashley, and D. Barr: Development of a Method to Assess Cigarette Smoke Intake; Environ. Sci. Technol. 38 (2004) 248-253.

32. Feng, S., S.E. Plunkett, K. Lam, S. Kapur, R. Muhammad, Y. Jin, M. Zimmermann, P. Mendes, R. Kinser, and H.J. Roethig: A New Method for Estimating the Retention of Selected Smoke Constituents in the Respiratory Tract of Smokers During Cigarette Smoking; Inhal. Toxicol. 19 (2007) 169-179.

33. West, J.B.: Respiratory Physiology: The Essentials; Lippincott Williams \& Wilkins, Philadelphia, USA, 2012.

34. Cooperation Center for Scientific Research Relative to Tobacco (CORESTA): CORESTA Recommended Method No 52: Environmental Tobacco Smoke Estimation of its Contribution to Respirable Suspended Particles - Method Based on Solanesol Determination; Cooperation Centre for Scientific Research Relative to Tobacco, (2002) available at: http://www.coresta. org/Recommended_Methods/CRMs.htm (accessed January 2016).

35. Moldoveanu, S.C., W. Coleman III, and J. Wilkins: Determination of Carbonyl Compounds in Exhaled Cigarette Smoke; Beitr. Tabakforsch. Int. 22 (2007)
346-357.

36. International Commission on Radiological Protection (ICPR): ICRP Publication 66: Human Respiratory Tract Model for Radiological Protection; Elsevier Health Sciences, 1994.

37. Majeed, S., S. Frentzel, S. Wagner, D. Kuehn, P. Leroy, P.A. Guy, A. Knorr, J. Hoeng, and M.C. Peitsch: Characterization of the Vitrocell ${ }^{\circledR} 24 / 48$ In Vitro Aerosol Exposure System Using Mainstream Cigarette Smoke; Chem. Cent. J. 8 (2014) 62 available at: http://www.http://journal.chemistrycentral.com/ content/8/1/62 (accessed January 2016).

38. Zhang, Z., C. Kleinstreuer, and Y. Feng: Vapor Deposition During Cigarette Smoke Inhalation in a Subject-Specific Human Airway Model; J. Aerosol Sci. 53 (2012) 40-60.

39. Rostami, A.A.: Computational Modeling of Aerosol Deposition in Respiratory Tract: A Review; Inhal. Toxicol. 21 (2009) 262-290.

40. Martonen, T.B. and C.J. Musante: Importance of Cloud Motion on Cigarette Smoke Deposition in the Lung; Inhal. Toxicol. 12 (2000) 261-280.

41. Zhang, Z., C. Kleinstreuer, and S. Hyun: Size-Change and Deposition of Conventional and Composite Cigarette Smoke Particles During Inhalation in a Subject-Specific Airway Model; J. Aerosol Sci. 46 (2012) 34-52.

42. Mathis, C., C. Poussin, D. Weisensee, S. Gebel, A. Hengstermann, A. Sewer, V. Belcastro, Y. Xiang, S. Ansari, S. Wagner, J. Hoeng, and M.C. Peitsch: Human Bronchial Epithelial Cells Exposed In Vitro to Cigarette Smoke at the Air-Liquid Interface Resemble Bronchial Epithelium From Human Smokers; Am. J. Physiol. Lung Cell Mol. Physiol. 304 (2013) 489-503.

43. Iskandar, A.R., F. Martin, M. Talikka, W.K. Schlage, R. Kostadinova, C. Mathis, J. Hoeng, and M.C. Peitsch: Systems Approaches Evaluating the Perturbation of Xenobiotic Metabolism in Response to Cigarette Smoke Exposure in Nasal and Bronchial Tissues; Biomed Res. Int. 2013 (2013) available at: http://www. ncbi.nlm.nih.gov/pmc/articles/PMC3808713/ (accessed January 2013)

44. Fukano, Y., H. Yoshimura, and T. Yoshida: Heme Oxygenase-1 Gene Expression in Human Alveolar Epithelial Cells (A549) Following Exposure to Whole Cigarette Smoke on a Direct In Vitro Exposure System; Exp. Toxicol. Pathol. 57 (2006) 411-418.

Corresponding author:

Shinkichi Ishikawa

Scientific Product Assessment Center, R\&D Group

Japan Tobacco Inc.

6-2, Umegaoka, Aoba-ku

Yokohama, Kanagawa 227-8512

Japan

E-mai: shinkichi.ishikawa@jt.com 